\title{
Request for Co-Operation in Experiment
}

\section{Author(s): E. A. Reeves}

Source: The Geographical Journal, Vol. 56, No. 3 (Sep., 1920), pp. 239-240

Published by: geographicalj

Stable URL: http://www.jstor.org/stable/1781555

Accessed: 26-06-2016 20:29 UTC

\section{Your use of the JSTOR archive indicates your acceptance of the Terms \& Conditions of Use, available at}

http://about.jstor.org/terms

JSTOR is a not-for-profit service that helps scholars, researchers, and students discover, use, and build upon a wide range of content in a trusted digital archive. We use information technology and tools to increase productivity and facilitate new forms of scholarship. For more information about JSTOR, please contact support@jstor.org.

The Royal Geographical Society (with the Institute of British Geographers), Wiley are collaborating with JSTOR to digitize, preserve and extend access to The Geographical Journal 
requests for auxiliary liquid compasses were received at the Admiralty." Early in this century Mr. D. Buckney made a small alteration in the design which unexpectedly cured the manœuvring defect. "Further improvements rapidly followed, the result being patented under the name of the Chetwynd Compass, and in 1908 the triumph of the liquid compass was complete, and it was introduced generally into the Navy. The foundation of this great success was laid by Captain Creak. ... The merit of hitting on the remedy that baffled him belongs, however, to another, and no one rejoiced more heartily at his success than Captain Creak."

These are the leading facts in the history : and it will be noticed that Captain Tizard, in the notice from Nature quoted by Mr. Creak, omits reference to the improvement made by Mr. Buckney after Captain Creak had retired in I90I, and to the fact that the compass eventually adopted in 1908 was patented and introduced into the Navy under another name. For this reason we wrote, in continuation of the sentence quoted by Mr. Creak: "and there is therefore some danger that the merits of his work, which so nearly reached success and so materially contributed to it, may escape notice ;" and we are glad of the occasion to summarize the very thorough account given by Sir Mostyn Field; which is indispensable for a complete understanding of the history.-ED. G.F.

\section{Request for Co-operation in Experiment.}

As the result of some experiments that I. and others have been making privately, it is found that a piece of thin dry paper, or other light material, freely suspended under a glass shade and protected from the wind and the direct rays of the sun,. will, under suitable conditions, indicate approximately the true north and south direction.

I am most desirous of getting this tested in other parts of the world, and am writing to ask if any of your readers abroad could manage to try the experiment and let me know the results. No great accuracy is expected, but in this country it has been found that the mean of several observations comes out within a very few degrees of the true north and south line, and sometimes to the nearest degree. In Canada and the United States, so far as the experiment has been carried out, much the same result has been obtained.

A suitable apparatus consists of a large wide-mouthed glass bottle, 12 or 15 inches in diameter, with a tight-fitting stopper, preferably of india-rubber, from the under side of which is suspended by a single fibre of unspun silk (at least 6 inches long if possible), a piece of flat thin paper, preferably of oval form, and about 2 inches long and $I \frac{1}{2}$ inches broad. The under side of the stopper from which the paper is suspended is covered with paraffin wax, and the bottle is coated inside and out with a thin transparent layer of shellac varnish. The bottle stands

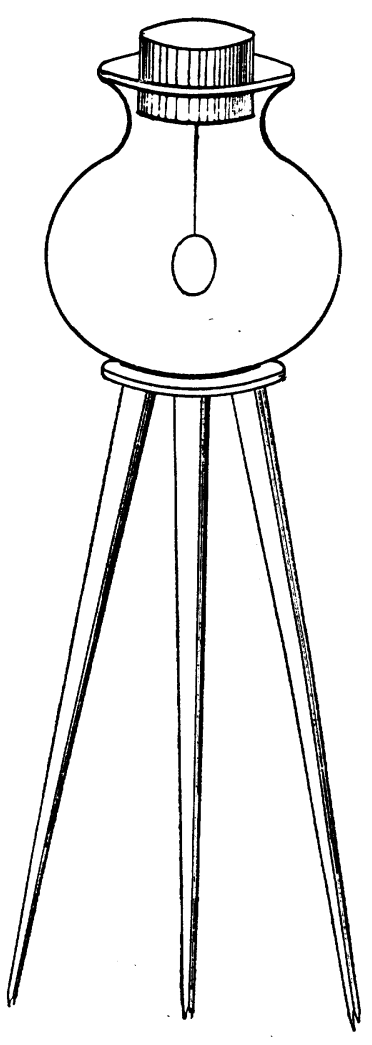


on a small circular receptacle, made of glass or wood, mounted on the top of a wooden tripod stand, as shown in the figure.

To carry out the experiment proceed as follows:-

I. On a fine, calm day (preferably between the hours of 7 and 10 a.m. or p.m.), when the barometer is fairly high and steady and the sky practically cloudless, set up the apparatus on a bare hilltop (or the highest open ground available) with no higher ground, trees, or other objects in the neighbourhood.

2. Level the tripod, and adjust the legs so. that the paper hangs in the centre of the bottle. Screen the bottle from the direct rays of the sun by some shading arrangement, such as an umbrella on a pole, not placed too near it.

3. After the paper has had time to take up its position and settle down (usually from fifteen to twenty minutes), take its bearing, viewed end on, with a prismatic or ordinary compass, making due allowance for variation. Although occasionally the paper comes to rest, it is usually found to oscillate evenly on either side of the true north and south line, in which case the mean position of its oscillations is taken. The bearing should be observed several times and the mean accepted. If the bottle is turned round through a considerable angle, the paper will take up about the same direction again if sufficient time is allowed, which may be about twenty minutes or half an hour, although sometimes much less is sufficient.

It is occasionally an advantage to electrify the paper before placing it in the bottle by touching it with a piece of vulcanite rubbed on a dry cloth, but generally this is not necessary. It is important to stand at a distance from the apparatus, not nearer than 3 or 4 yards, after it has been set up. The bottle must be kept dry, and it is useless to attempt the experiment except in fine dry weather with a practically cloudless sky, little or no wind, and a fairly high barometer. The best hours to try the experiment, at any rate in the summer, appear to be those given above, but fairly satisfactory results have been obtained at all hours of the day.

This experiment arises out of some investigations I have been making in Terrestrial Magnetism and the question of the existence of an electric field in the atmosphere with the mean normal direction of its lines of force approximately parallel with the rotation axis of the Earth (see my paper in the Geographical. Journal for March 1919). I shall be very grateful if any who have the opportunity of making this experiment in other parts of the world will send me the results, whatever they may be, for it will be of great interest to know whether in general a light body so suspended tends to take up a definite direction, and what that direction may be.

E. A. REeves,

Map Curator and Instructor in Surveying, Royal Geographical Society.

Kensington Gore, S.W. 7, July $\mathbf{1 9 2 0 .}$ 